\title{
A New Attestation of the Cult of Zeus Trossou in a Public Inscription from the Upper Maeander River Valley (Çal Ovası)
}

\author{
Esengül AKINCI ÖZTÜRK* - Hasan Hüseyin BAYSAL** - Marijana RICL***
}

From the village of Akkent north of Çal, found at a place called Dikilitaş mevkii and subsequently transferred to the storeroom of the Belediye (municipality) of Çal. White-marble block broken above and damaged on all sides. On the front side of the block is an inscription of twenty-two lines: of the first nine lines only some letters at the beginning of each are preserved, since the surface of the stone was subsequently reworked and a part of the text destroyed in the process; furthermore, a large piece of the stone's surface is broken off on the right side of the same area. Dimensions: height 0.72; width 0.48; thickness 0.16; letters 0.015-0.02 (lines 1-13), 0.013-0.015 (lines 14-22).

Date: Roman Imperial Period

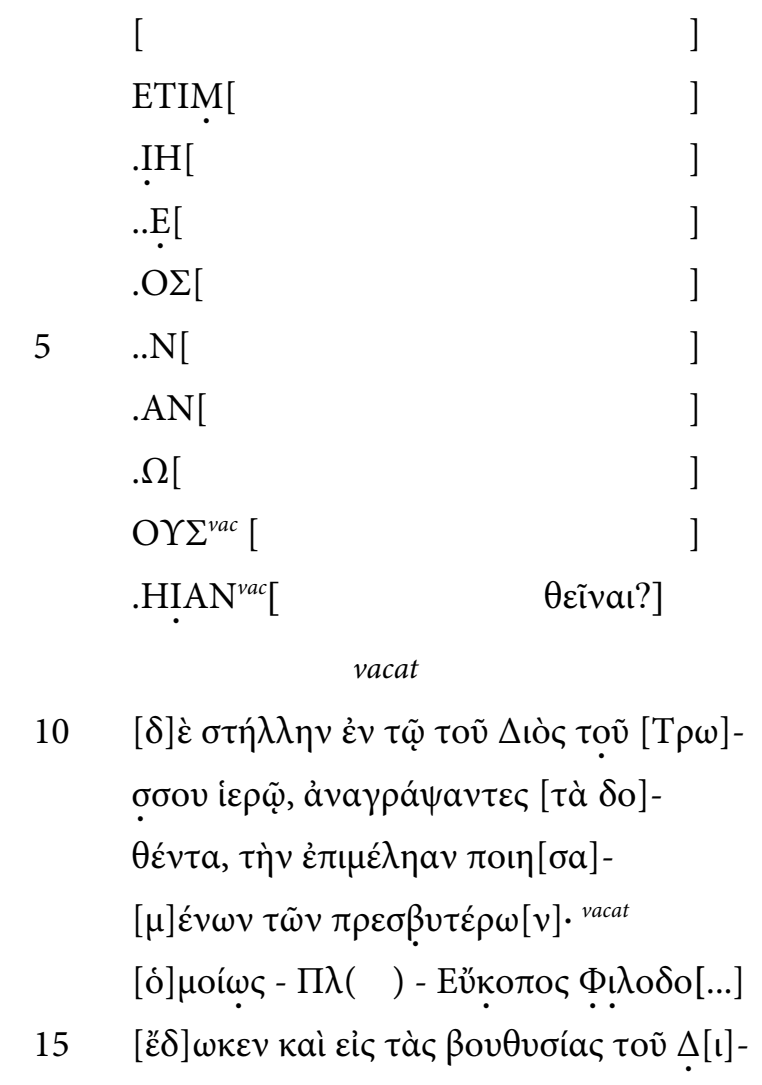

*Yrd. Doç. Dr. Esengül Akıncı Öztürk, Pamukkale Üniversitesi, Fen-Edebiyat Fakültesi, Arkeoloji Bölümü, A Blok Zemin Kat, 20070 Kınıklı/Denizli (eakinci@pau.edu.tr).

${ }^{* *}$ Hasan Hüseyin Baysal, director of Denizli Museum, Pamukkale (Hierapolis) Örenyeri Kuzey Kapısı İdari Bina, Pamukkale/Denizli (h.huseyinbaysal@gmail.com).

*** Prof. Dr. Marijana Ricl, University of Belgrade, Faculty of Philosophy, Department of History, Serbia (mricl@f.bg.ac.rs).

We would like to thank Mustafa Tekin for finding the monument and informing us about its whereabouts and Hasan Malay for his generous help and advice in reading the inscription. 


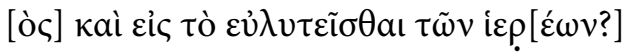

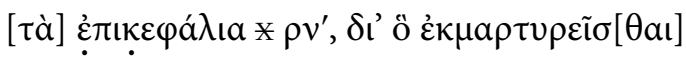

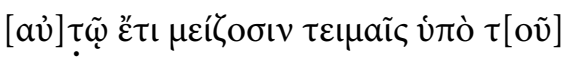

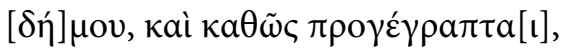

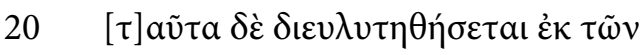

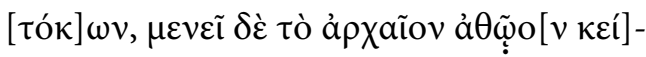

$[\mu \varepsilon] v o v ? \tau \tilde{\omega} \delta \dot{\eta} \mu[\omega] .{ }^{v a c a t}$

- - and a stele [is to be set up] in the sanctuary of Zeus [Tro]ssou after (a list of) the donations is inscribed under the supervision of the elders; similarly, $\mathrm{Pl}$ ( ) Eukopos, son of Philodo[xos(?)] [do]nated both for the sacrifices of oxen to Zeus and for the payment of the prie[sts'?] poll-tax 150 denarii, on which account let him receive a testimonial from the people in the form of even greater honours; furthermore, as stated above, these expenses will be perpetually defrayed from the interest, while the principal will remain intact to the people.

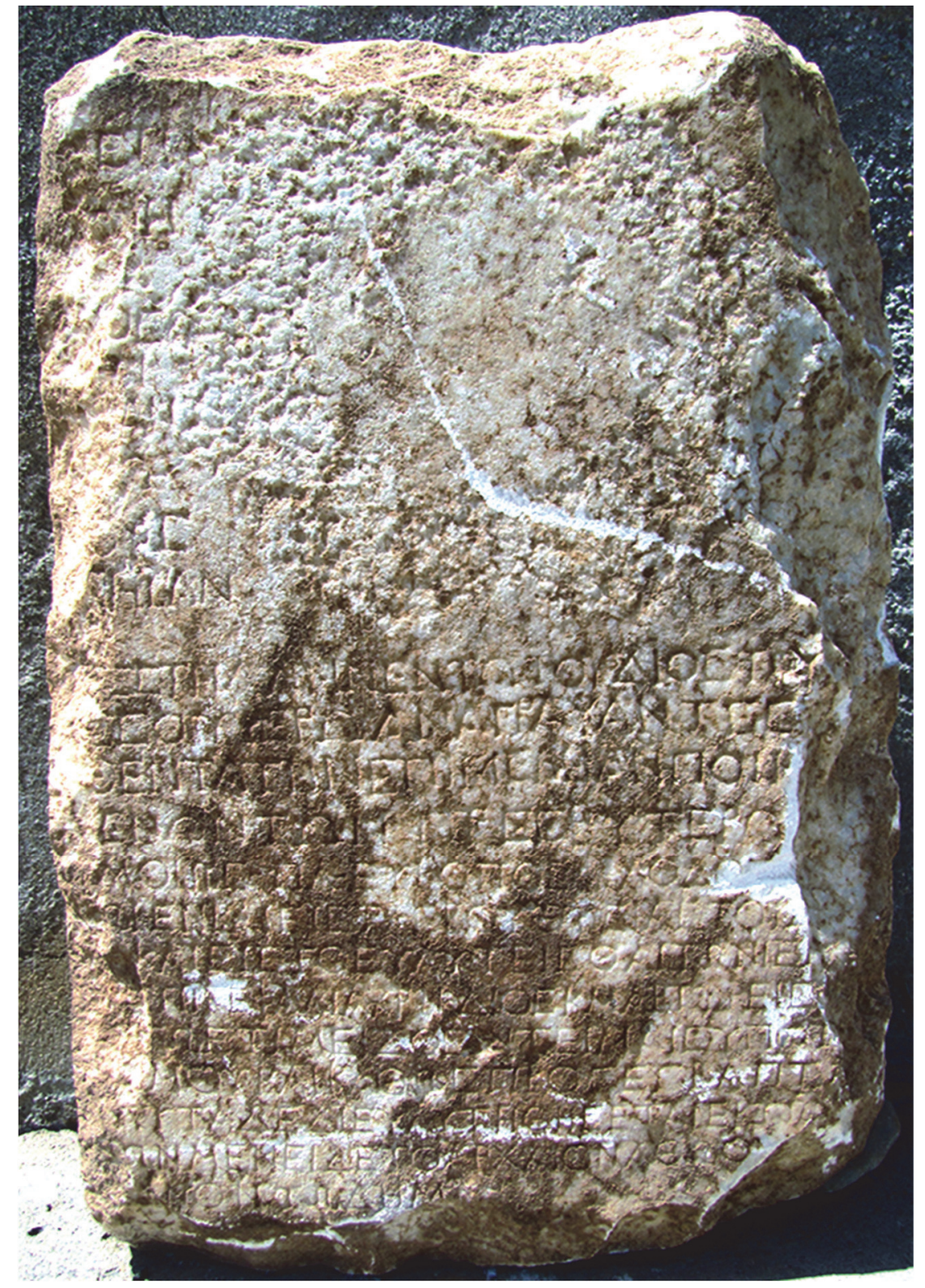


It proved challenging to decide if the damaged surface on the upper part of the stone originally contained continuous lines of letters comparable to those present on the lower half of the block, or a molded wreath - there is a clearly noticeable round, wreath-like outline in this part of the block ${ }^{1}$ initially encircled ${ }^{2}$ by the first nine lines of the inscription. In favour of the second option are the following points: there seem to be no traces of letters on the preserved part of the inner surface of the conjectural wreath, no letters were carved after OY $\Sigma$ in line 8 and HIAN in the following one, although there was an adequate space for a couple of letters next to the putative wreath ${ }^{3}$, and line 10 starts below a space intentionally left vacant, presumably in order to inscribe it in scriptio continua. On the other hand, the letters HIAN, at the beginning of line 9 cannot be smoothly joined to the beginning of the first completely preserved line 11, but there is also a possibility that some letters from the same line originally stood on the missing right border of the stone; $1 \dot{\varepsilon} \tau i[\mu \eta \sigma \alpha v]$ ?; 9 the second letter in this line could be a beta, since on the squeeze one notices a lower horizontal hasta too short for an epsilon or a sigma; 11/12 there is not enough place to supply [ $\tau \grave{\alpha}$ à $v \alpha \mid \tau \varepsilon] \theta \varepsilon ́ v \tau \alpha$, but enough for [ $\tau \grave{\alpha} \delta o] \mid \theta \varepsilon \dot{v} \tau \tau$ : if that is a correct supplement, than what was to be inscribed on the stele was a list of private donations destined to the community of Atyochorion, and actually lines 14-17 contain the name of a donor and the amount of his donation; 14 from this line onwards, starting with [ó] $\mu$ oí $\omega \varsigma, \Omega$ displays a different, more slender form with ends bent upwards and keeps it till the end of the inscription; moreover, $\Delta$ and $\mathrm{M}$ assume slightly modified forms when compared to the same letters in the preceding lines, and lastly, from line 14 onwards letters are generally smaller, suggesting that perhaps the final part of the inscription was engraved at a later date; letters $\Pi \Lambda$ are separated from the rest by two short horizontal dashes clearly observable on the photographs and the squeeze of the inscription: this suggests an abbreviation, possibly of a Latin nomen (e.g., Placidius, Plautius, Plinius, Plotius); following that is a personal name, either Eüколоৎ or, less likely, Eúролоৎ, both of which were so far attested only in two Latin inscriptions - Eukopos in the form Eucopio in Rome ${ }^{4}$,

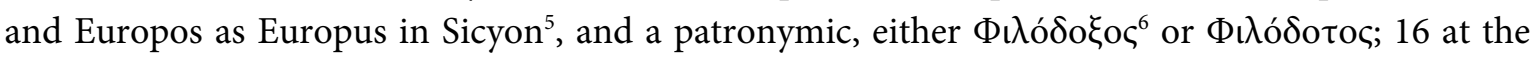

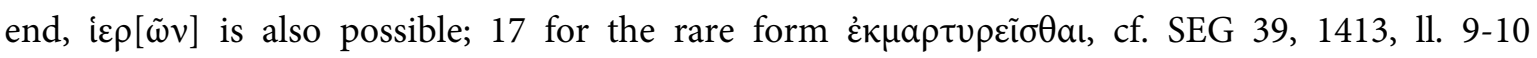

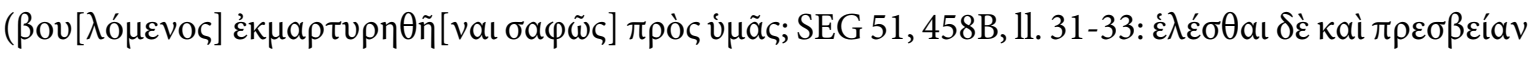

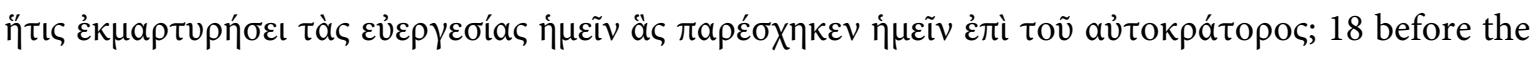
initial omega one sees the final part of an upper horizontal hasta belonging most probably to a tau; 21-22 the word $\dot{\alpha} \theta \tilde{\omega} \mathrm{o}[\mathrm{v}]$ is certain, but we were unable to find a parallel for its use in this context, to

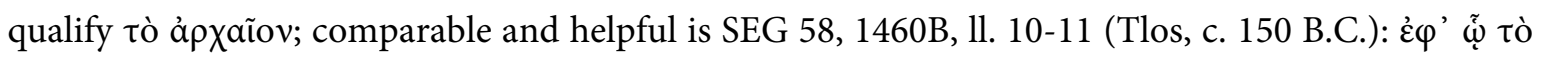

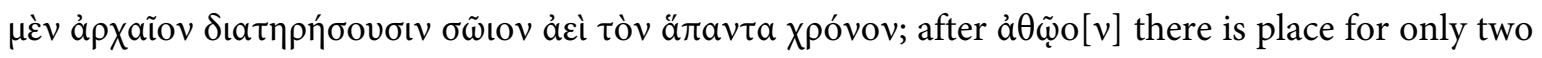

\footnotetext{
${ }^{1} \mathrm{H}$. Malay kindly suggested in his e-mail message of September 28, 2015, that the chiseled surface does not have any traces of a wreath and that the wreath-like round outline is due to the fact that this part of the stone may have been prepared to provide a rough surface on which to place a column.

${ }^{2}$ And possibly also carrying some letters on its surface.

${ }^{3}$ Hypothetically, the stonecutter was reluctant to start a new word and separate it in two parts by the relief.

${ }^{4}$ CIL VI 17313 (ILS 8487): D(is) M(anibus) | Eucopionis qui | vixit m(ensibus) VI, d(iebus) III, in|fanti dulcissimo | suavissimoque, qui | cum nondum fa|ri potuisset, iucun|dissimo. L(ucius) Curio Terminalis | item Verna | et Sosipatra | parentes | fec(erunt).

${ }^{5}$ ILGR p. 42 no. 82: V(ivus) M(arcus) Calpetanus Co|rinthus sibi et Fulviae | Eutychidi uxori et Cal|petanis Ianuario et Ma|gna(e) liberis et $\mathrm{M}(\operatorname{arco})$ Pacu(v)io Europo et libertis.

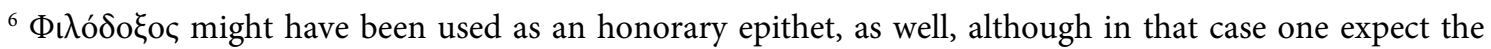
article ó to precede it.
} 
or three letters, and the same number can fit before NON in the following line, so that we propose to $\operatorname{read}[\kappa \varepsilon i \mid \mu \varepsilon] v o v$, realizing that $[\sigma \omega \mid \zeta o ́ \mu \varepsilon] \nu o v$ or $[\tau \eta \mid \rho o v ́ \mu \varepsilon] v o v$ would also be possible, although somewhat too long for the available space.

The new public inscription comes from the modern village of Akkent situated in the great bend of the Maeander River, on the left bank of the river itself and about $9 \mathrm{~km}$ northwest of Çal as the crow flies. The village was previously known under the name of Zeive. M. Ricl and E. Akıncı Öztürk recently published another inscription from Akkent ${ }^{7}$, bringing the total number of inscriptions from

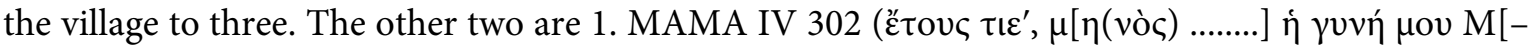
- - ] + on the left side of the stele, opposite line 1: [- - ] кai); 2. Ramsay 1883, 383-384 no. 6 (MAMA

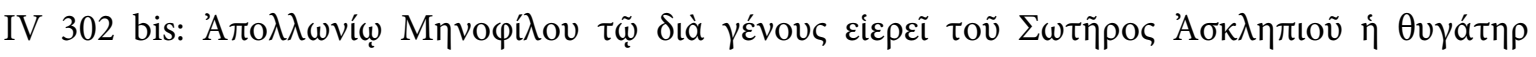

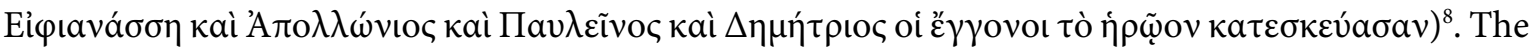
ethnic Atyochoreites ${ }^{9}$ used for the same Apollonios, son of Menophilos, in the inscription from Bahadinlar adduced in note 8 suggests that Apollonios' birthplace originally had the status of a village community on the territory of a city (Dionysopolis?). In a recently published inscription of unknown provenance ${ }^{10} \mathrm{kept}$ in the Museum of Denizli and dated in 169 A.D. ${ }^{11}$, Atyochorion reappears with a

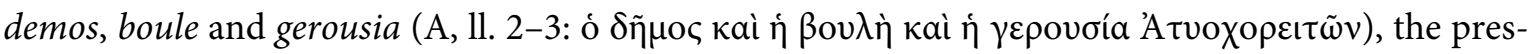
ence of these three constitutional elements together suggesting that at some point in time the village was elevated to the status of a city ${ }^{12}$. The third inscription from Akkent, published previously by Ricl and Akıncı Öztürk and preserving a part of a decree honouring a community's own deserving mem-

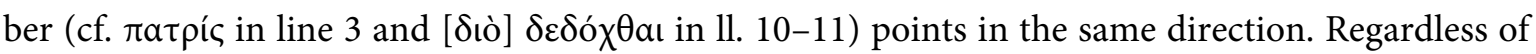

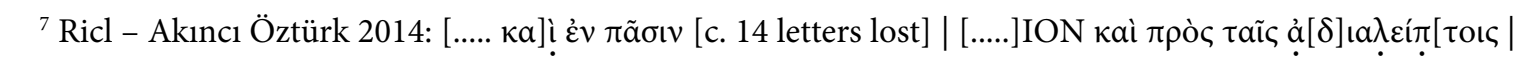

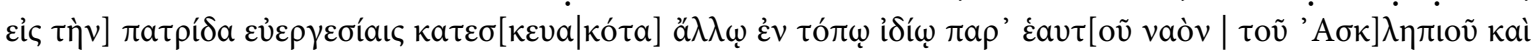

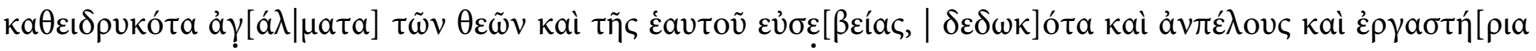

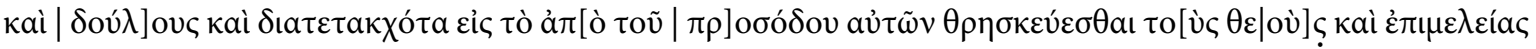

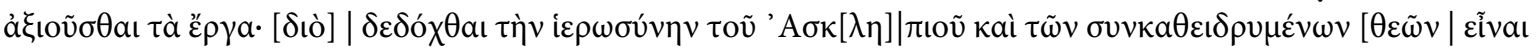
- - - ].

${ }^{8}$ Apollonios, son of Menophilos and his daughter Iphianassa, along with a son named Laomedon who most probably predeceased his father, appear in another inscription found at Bahadinlar northwest of Akkent (Ram-

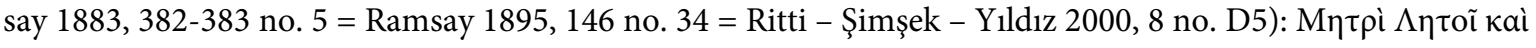

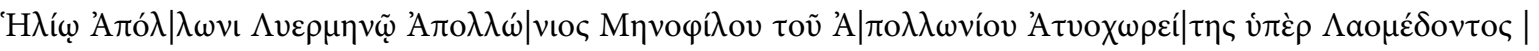

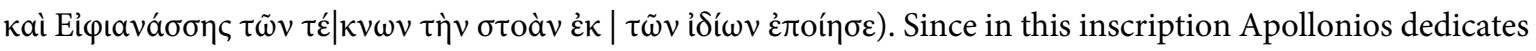
a stoa to Meter Leto and Helios Apollo Lyermenos on behalf of his children, the stone was presumably brought to Bahadinlar from the site of the sanctuary of Apollo Lairbenos and his Mother situated at the place called Asartepe (on this sanctuary, see most recently Akıncı Öztürk - Tanrıver 2008, with earlier bibliography).

9 Two more natives of Atyochorion can be found in Akıncı Öztürk - Tanrıver 2008, 96 no. 5 (SEG LVIII 1526, 223/4 A.D.) and 96-97 no. 6 (SEG LVIII 1523, 215/6 A.D.). On Atyochorion itself, see Robert 1962, 129-

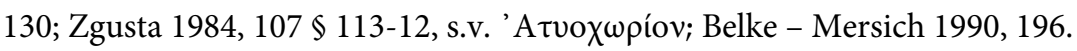

${ }^{10}$ By now, we think it is almost certain that this stone originates from Akkent, as well.

${ }^{11}$ Ritti 2002, 66-69 (SEG 52, 1333).

12 The comment of the first editor on p. 68 is unspecific: 'L'abitato di Atyochorion appare qui come un agglomerato in possesso di una propria organizzazione di governo locale, funzionante attraverso un'assemblea e un consiglio, ed anche di una associazzione degli anziani.' Later on (p. 69), she labels it 'villaggio'. In any event, the name of the community having as its constituent part the word $\chi \omega$ piov should not be used as evidence against its possible polis-status (cf. TAM II 168, $2^{\text {nd }} / 1^{\text {st }}$ c. B.C., from Hippoukome in Lycia, a full-fledged polis). 
the stance we choose to adopt regarding the question of its status, we should probably locate ancient Atyochorion at or near modern Akkent ${ }^{13}$.

The new inscription from Akkent/Atyochorion is the third official inscription from this place out of five inscriptions originating from the same site, and simultaneously the third honorific one. The first honorific inscription is engraved on a statue-base for one Dionysios erected by the people, council and gerousia of Atyochorion (cf. note 11), while the second honours an anonymous benefactor who had built "[a temple/altar] of Asklepios and dedicated s[tatues] of the gods and of his own piety; he had likewise given vineyards and workshops and [slave]s and assigned them (to the sanctuary) so that the profits thereof be used for the performance of ritual observances for the gods and the maintenance of the (sacred) installations; [on account of this], it was resolved that the priesthood of Asklepios and the [gods] consecrated together with him - - " (cf. note 7).

The new inscription preserves a part of a decree of the community of Atyochorion stipulating that a stele with a list of some donations/dedications will be erected in the sanctuary of Zeus Trossou and that the presbyteroi will supervise this operation. The cult of Zeus Tros(s)ou is a well-known cult of Roman Phrygia previously attested in three or four inscriptions originating from the same region of the upper Maeander River valley as the new inscription. They are the following ones: 1. J. Keil, 'Zeus Trosou', Anz. Akad. Wien, philos.-hist. Kl. 87, 1950, pp. 83-85 (Bull. épigr. 1951, 211, 'Mons Dindymus'); 2. MAMA IV 268 (Bahadinlar); 3. probably also MAMA IV 266 (Kuyucak north of Akkent),

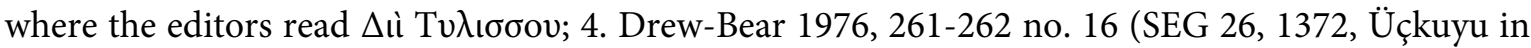
the same region but north of the Maeander River). A fifth attestation is found in a confession-inscription reportedly originating from Akçaavlu near Soma in southeastern Mysia and republished by Petzl 1994, 1-3 no. 1. The new inscription from Akkent/Atyochorion features the god's sanctuary, the sacrifices of oxen that took place there and the sanctuary's personnel, either the priests or the hieroi.

The presbyteroi entrusted with the supervision of the production and erection of the stele, were members of the gerousia of Atyochorion: as stated above, this organ is already attested for Atyochorion in an inscription from the Museum of Denizli ${ }^{14}$.

The concluding part of the inscription (lines 14-22) provides information on a donation of 150 denarii made by one Pl. Eukopos Philodo[...] to the demos of Atyochorion for the sacrifices of oxen to Zeus (Trossou) and for the payment of the priests' poll tax ${ }^{15}$. Because of this benefaction, he was

\footnotetext{
${ }^{13}$ This view is shared by Ritti - Şimşek - Yıldız 2000, 8 note 19 and again by Ritti 2002, 68.

${ }^{14}$ On the institution of gerousia in the Imperial period, cf. Dmitriev 2005, passim; Zimmermann 2007; Giannakopoulos 2008; Bauer 2014 (non vidimus). Less likely, although still not impossible, would be to view the presbyteroi of Atyochorion as a group of elders involved in the managment the cult of Zeus Trossou, comparable, e.g., to the sacred gerusia of Asklepios Soter in Boeotian Hyettos (IG VII 2808; Roesch 1982, 153 no. 21) or the 'second gerusia of Pluto' in Isaurian Astra (Royer - Bahar 2011, 155-156 no. 4).

${ }^{15}$ For other epigraphical attestations of the Roman poll-tax, see IBeroia 117 (end of $1^{\text {st }}$ c. A.D.); IG XII 5 , 724 (Andros, Hadrian); IG XII 5, 946 (Tenos, $1^{\text {st }} / 2^{\text {nd }}$ c. A.D.); SEG 14, 479 (IGBulg IV 2263, Parthicopolis, 158 A.D.); Robert - Robert 1954, no. 67 (Herakleia Salbake, Imperial period); ILampsakos 10 (Imperial period); IAssos 28 ( $2^{\text {nd }}$ c. A.D.); SEG 57, 1673 (Patara, Vespasian). On the tax itself, see Jones 1974, 151-185; Neesen 1980, 117-135 (esp. p. 128 on the amount payable in Egypt - from 10 to 40 drachmae, with one Alexandrian bronze drachma equivalent to one sestertius, as presented by Geissen 2012, 563); Brunt 1981; Corbier 1991, 629665, esp. 653-654; Potter 2004, 53-57.
} 
honoured by the people Ëंı $\mu \varepsilon$ í impressive to us, yet it still probably equaled five years of bare subsistence for an average Roman ${ }^{17}$. As already stipulated in the lost part of the inscription, the public expenses selected by the donor were to be covered form the generated interest on the donated sum, while the capital itself ( $\tau$ ò ả $\rho \chi a i o v)$ was to remain intact to the people of Atyochorion.

\section{Bibliography}

Akıncı Öztürk - Tanrıver

E. Akıncı Öztürk - C. Tanrıver, New Katagraphai and Dedications from 2008

Bauer 2014 the Sanctuary of Apollon Lairbenos, EpigrAnat 41, 2008, 91-111.

Belke - Mersich 1990

E. Bauer, Gerusien in den Poleis Kleinasiens in hellenistischer Zeit und der römischen Kaiserzeit, München 2014.

K. Belke - N. Mersich, Phrygien und Pisidien, Wien 1990 [Tabula Imperii Byzantini, Band 7].

Brunt 1981

Corbier 1991

P. A. Brunt, The Revenues of Rome, JRS 71, 1981, 161-172.

M. Corbier, Cité, territoire et fiscalité, in: Epigrafia. Actes du colloque international en mémoire de Attilio Degrassi (Rome, 27-28 mai 1988), Rome 1991 (Collection de l'École française de Rome, 143), 629-665.

Dmitriev 2005

S. Dmitriev, City Government in Hellenistic and Roman Asia Minor, Oxford 2005.

Drew-Bear 1976

Th. Drew-Bear, Local Cults in Graeco-Roman Phrygia, GRBS 17, 1976, 247-268.

Geissen 2012

A. Geissen, The Coinage of Roman Egypt, in: W. E. Metcalf (ed.), The Oxford Handbook of Greek and Roman Coinage, Oxford 2012, 561583.

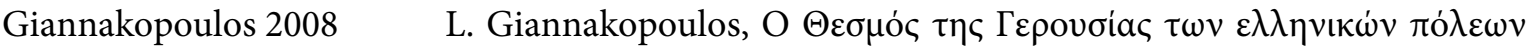

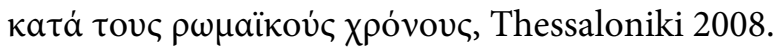

ILGR

M. M. Šašel Kos, Inscriptiones Latinae in Graecia repertae, Additamenta ad CIL III, Faenza 1979.

Jones 1974

A. H. M. Jones, Taxation in Antiquity, in: A. H. M. Jones (ed.), The Roman Economy: Studies in Ancient Economic and Administrative History, ed. by P. A. Brunt, Oxford 1974, 150-186.

Neesen 1980

L. Neesen, Untersuchungen $\mathrm{zu}$ den direkten Staatsabgaben der römischen Kaiserzeit (27 v. Chr.-284 n. Chr.), Bonn 1980.

Petzl 1994 G. Petzl, Die Beichtinschriften Westkleinasiens, Bonn 1994 [EpigrAnat 22].

Potter 2004 D. Potter, The Roman Empire at Bay AD 180-395, London 2004.

\footnotetext{
${ }^{16}$ For this phrase and its use to indicate additional honours bestowed on an individual, cf. IG II $^{3} 1218$; SEG

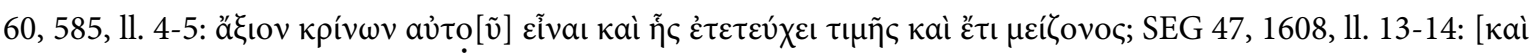

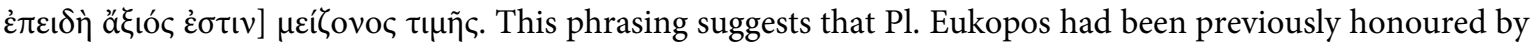
Atyochorion on an unknown occasion, perhaps in connection with another donation of his.

${ }^{17}$ Zuiderhoek 2009, 4.
} 
Ramsay 1883

Ramsay 1895

Ricl - Akıncı Öztürk 2014

Ritti 2002

Ritti - Şimşek - Ylldız

2000

Robert - Robert 1954

Robert 1962

Roesch 1982

Royer - Bahar 2011

Zgusta 1984

Zimmermann 2007

Zuiderhoek 2009
W. M. Ramsay, The Cities and Bishoprics of Phrygia, JHS 4, 1883, 370436.

W. M. Ramsay, The Cities and Bishoprics of Phrygia, Being an Essay of the Local History of Phrygia from the Earliest Times to the Turkish Conquest, Vol. I, Parts I-II, Oxford 1895-1897.

M. Ricl - E. Akıncı Öztürk, A New Benefactor from the Upper Meander Valley (Çal Ovası), EpigrAnat 47, 2014, 16-20.

T. Ritti, Documenti epigrafici dalla regione di Hierapolis, EpigrAnat 34, 2002, 41-70.

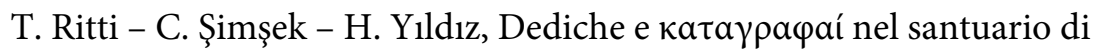
Apollo Lairbenos, EpigrAnat 32, 2000, 1-88.

J. Robert - L. Robert, La Carie, II. Le Plateau de Tabai et ses environs, Paris 1954.

L. Robert, Villes d'Asie Mineure. Études de géographie ancienne, Paris ${ }^{2} 1962$.

P. Roesch, Études béotiennes, Paris 1982.

A. Royer - H. Bahar, Astra en Isaurie, Anatolia Antiqua 19, 2011, 149198.

L. Zgusta, Kleinasiatische Ortsnamen, Heidelberg 1984.

$\mathrm{K}$. Zimmermann, La origine de la gérousie de l'époque impériale, in: $\mathrm{M}$. Mayer - G. Baratta - A. Guzman Almagro (edd.), XII Congressus Internationalis Epigraphiae Graecae et Latinae (3-8 septembre 2002, Barcelona), Barcelona 2007, 1523-1528.

A. Zuiderhoek, The politics of Munificence in the Roman Empire: Citizens, Elites and Benefactors in Asia Minor, Cambridge 2009. 


\section{Yukarı Menderes Vadisi'nde (Çal Ovası) Bulunan, Zeus Trossou Kültüne İlişkin Yeni bir Kamu Yazıtı Özet}

Makalede, Çal'ın kuzeyindeki Akkent kasabasında (Atyokhorion) bulunmuş olan ve Roma İmparatorluk Dönemi'ne tarihlenen yeni bir resmî yazıt incelenmektedir. Üst bölümü oldukça yıpranmış durumdaki bu Yunanca yazıtın okunabilen kısmında, Pl. Eukopos adındaki yerel bir hayırseverin yaptığı bağışlar kaydedilmektedir. Buna göre Eukopos, Zeus Trossou’ya boğa kurban edilmesi (bouthysia) ve rahiplerin kelle (bireysel) vergilerinin ödenmesi için 150 denarius bağış yapmıştı. Ancak bu masraflar sürekli olarak Eukopos’un bağışladığı paranın faizinden karşılanacak ve anapara Halk’a ait olacaktı. Yazıtın aşınmış olan üst bölümünde, Yaşlılar Meclisi'nin (gerousia) kontrolü altında sunulmuş olan adakların/bağışların bir listesi yer almaktaydı. Yazıtın çevirisi şöyledir:

“... ve Yaşlılar Meclisi'nin denetimi altında bağışların bir listesi yapıldıktan sonra, bu listenin yazıldiğı bir stelin Zeus Trossou Tapınağı’na dikilmesine (karar verildi). Aynı şekilde, Philodoksos oğlu Pl. Eukopos, hem Zeus'a boğa kurban edilmesi (bouthysia) ve hem de rahiplerin kelle (bireysel) vergilerinin ödenmesi için 150 denarius bağışlamıştır. Bu nedenle, halkın takdirini ifade etmek üzere kendisine çok daha büyük onurların verilmesine (karar verildi). Ayrıca, yukarıda da belirtildiği gibi, tüm masraflar bu paranın faizinden karşılanacak ve anapara Halk'a ait olacaktır".

Anahtar Sözcükler: Atyokhorion; hayırsever; bağış; Zeus Trossou; onurlandırma; gerousia; bouthysia; kelle vergisi; rahip; anapara; faiz.

\section{A New Attestation of the Cult of Zeus Trossou in a Public Inscription from the Upper Maeander River Valley (Çal Ovası) \\ Abstract}

This article contains the publication of a new public inscription from the village of Akkent north of Çal (ancient Atyochorion). The inscription dates from the Roman Imperial period and its upper half is heavily damaged. The remaining part of the inscription contains information about a local benefactor Pl. Eukopos, son of Philodoxos (?), who donated 150 denarii for the sacrifices of oxen to Zeus Trossou and for the payment of the priests' poll tax, under the condition that the expenses are perpetually defrayed from the interest, while the principal remains intact to the people. The lost part of the inscription contained a list of similar dedications/donations, erected under the supervision of the members of local gerousia.

Keywords: Atyochorion; benefactor; donation; Zeus Trossou; honorary inscription; gerousia; bouthysia; poll tax; priests; capital; interest. 